\title{
SOME MORPHOLOGICAL STRUCTURES OF THE APHID PARASITOIDS (HYMENOPTERA, APHIDIIDAE-HOMOPTERA, APHIDOIDEA)
}

https://doi.org/10.53937/9789975315975.36

\section{Chiriac lon}

Institute of Zoology, 2028 Chișinau, Republic of Moldova

The main morphological structures used in genus key of determination are fore wing veins, ovipositor sheath (valvulae 3), valvulae 2, tergite 1, propodeum, mezothorax and others. Mackauer, 1961 divided family Aphidiidae into 4 subfamilies: Ephedrinae, Praoninae, Aclitinae and Aphidiinae. We ascertain that valvulae 2 has only two morphological structures, one with hook and other without it which is only sharp. The role of hook in oviposition case is to not let go the aphid. That morphological structure is established at Ephedrinae, with exception of genus Toxares Haliday, 1833 which is sharp and ovipositor sheath is deltaforming; at Praoninae: genus Areopraon Mackauer, 1959; Pseudopraon Stary, 1975; Praon Haliday, 1833; Dyscritulus Hincks, 1943; at Aphidiinae: genus Prothaphidius Ashmead, 1900; Remaudierea Stary, 1973; Aphidius Nees 1811; Indaphidius Stary, 1979; Kashmiria Stary, Bhagat, 1978; Lysaphidius Smith, 1944; Paralipsis Foerster, 1862; Lysiphlebia Stary, Schlinger, 1967; Lysiphlebus Foerster, 1862; Adyalitus Foerster, 1862; Diaeretus Foerster, 1862; Diaeretiella Stary, 1960; Diaeretellus Stary, 1960; Vanhartenia Stary, 1974; Falciconus Mackauer, 1959; Monoctonus Haliday, 1833; Monoctonia Stary, 1962.

With both tip of valvulae 2 are at genus Pauesia Quilis, 1934. With sharp of valvulae 2 are at following genus: Lipolexis Foerster, 1862; Bioxys Sary, Schlinger, 1967; Betuloxys Mackauer 1960, Trioxys Haliday, 1833; Acanthocaudus Smith, 1944; Cristicaudus Stary, Remaudiere, 1982.

In oviposition act, the rule of not let go the aphid are the prongs of last sternite, form of ovipositor sheaths which is bent up. In oviposition the abdomen is bent down between legs, so ovipositor sheaths press the victim to surface. 
Between others morphologic structures at Praoninae, except spinning the cocoons outside of aphid is labium, superior lip, which is rounded at far margin with rare spurs. At subfamily Ephedrinae, Aclitinae, Aphidiinae at tip of labium has an appendix in form of sausage covered with dens small hairs. At Praoninae the coxae of middle legs have a band of mesosternum at hind, but at Ephedrinae without that band. At Prainae the marginal hind part of hind wing have a hairs with the some length, but at Ephedrinae with different hairs.

Based on thouse morphologic structures was made a key for genus of world parasitoids.

Studiile au fost realizate în cadrul proiectului bilateral AȘM-ASȘIIU, 17.80013.5007.05/Ua. 